$1-7$

Accepted: March 2, 2019

http://ejournal-kertacendekia.id/index.php/nhjk/

(C) 2019 Nurse and Health: Jurnal Keperawatan

\title{
THE EFFECT OF THE SKIN PERSONAL HYGIENE MODULES AS HEALTH EDUCATION MEDIA AGAINST KNOWLEDGE IN PREVENTION OF SKABIES
}

\author{
Lono Wijayanti ${ }^{1 *}$, Nur Ainiyah ${ }^{1}$ \\ ${ }^{1}$ Faculty of Nursing and Midwifery, Universitas Nahdlatul Ulama, Surabaya, East Java \\ 60115, Indonesia \\ *Correspondence: \\ Lono Wijayanti \\ Email: lono@unusa.ac.id
}

\begin{abstract}
Background: Scabies is often called body lice caused by mites Sarcoptes scabei. Scabies is often overlooked because it is not lifethreatening so the priority for treatment is low, but chronic and severe scabies can cause dangerous complications (Harahap, 2008). This typical boarding disease is very closely related to the culture and values that exist in the Islamic boarding school environment. The students who suffer from scabies have complaints that they often itch at night so they can disturb their rest or sleep at night.

Objectives: This study aimed to the effect of the skin personal hygiene modules as health education media against knowledge in prevention of skabies in the Islamic boarding school Roudhotul Muta'alimin Muta'alimat, Jabon Sub-District, Sidoarjo District, East Java Province, Indonesia.

Methods: The study design was used pre-experiment (one group pretest posttest). The population is all of students who lives in the Islamic boarding school Roudhotul Muta'alimin Muta'alimat, Jabon Sub-District, Sidoarjo District, East Java Province, Indonesia, amounting to 72 students. The sample of this study was 60 students using simple random sampling. The research instruments were skin personal hygiene modules and questionnaires. Data was analyzed using the Wilcoxon Signed Ranks Test.

Results: The results showed that the level of knowledge before and after being given health education using the skin personal hygiene module was an increase, based on the Wilcoxon Signed Ranks Test analysis showed a difference with a significant value $p=0,000$ and significance level $\alpha<0.05$.

Conclusion: Health education using the skin personal hygiene module had a positive impact on increasing the knowledge of the students at the Islamic boarding school Roudhotul Muta'alimin Muta'alimat Jabon Sidoarjo. Health education through counseling can be used to maintain and improve the health of the students in preventing scabies.
\end{abstract}

Key words: The skin personal hygiene module, knowledge, health education, Scabies.

\section{INTRODUCTION}

Islamic boarding school education is one of the religious education institutions that grows and develops in the community which plays an important role in forming a healthy lifestyle. Islamic boarding schools where students usually stay with friends in one room. Staying with a group of people, such as at a Islamic boarding school is at risk of easily contracting various diseases, such as scabies, so it needs special attention, especially health and growth.

Scabies is a skin disease caused by mite Sarcoptes scabei, which belongs to the Arachnida class. Scabies is often called body lice. Scabies easily spreads directly 
through the touch of the skin with sufferers or indirectly through clothes, sheets, towels, pillows, water or combs that have been used by patients who have not been cleaned, so that Sarcoptes mites are still present on these devices (Harahap, 2008).

Scabies is often overlooked because it is not life threatening so the priority for treatment is low, but chronic and severe scabies can cause dangerous complications. Scabies causes discomfort because it causes very itchy lesions. As a result, sufferers often scratch and cause secondary infections, especially by bacteria Group A Streptococci (GAS) and Staphylococcus aureus (Golant, Levitt, 2012).

According to World Health Organization (WHO), the prevalence of scabies worldwide is reported to be around 300 million cases per year (Chosidow, 2006). In industrial countries such as Germany, scabies occurs sporadically or in long endemic forms (Ariza et al, 2012). Baur (2013) reported the prevalence of scabies in India as much as $20.4 \%$. Zayyid (2010) reported the prevalence of scabies as much as $31 \%$ in the children with aged 1012 years old. According to the Indonesian Ministry of Health, the prevalence of scabies in health centers throughout Indonesia in 2009 was $4.6 \%-12.95 \%$ and scabies was ranked third out of 12 most common skin diseases, 704 cases of scabies were found which constituted $5.77 \%$ of all new cases. In 2011 and 2013, the prevalence of scabies was $6 \%$ and $3.9 \%$. Scabies in Indonesia ranks third in the 12 most common skin diseases (Azizah, 2013). The incidence and prevalence of scabies is still very high in Indonesia, especially in the pesantren community. This is evidenced by the results of the Kuspiantoro (2009) study, which found that the prevalence of scabies in Pasuruan Islamic boarding schools was $70 \%$.

Health improvement efforts are very necessary, namely with Skin Personal Hygiene, where the skin is the body's first defense against infection. To get good and correct personal hygiene, good knowledge is needed, so that the maintenance of good personal hygiene is created. The skin is an elastic wrap that protects the body from environmental influences. One part of the human body that is very sensitive to various diseases is skin (Harahap, 2008).

Factors that play a role in the high prevalence of scabies, especially in developing countries, are related to poverty associated with low levels of cleanliness, difficult access to water, and density of housing. The high occupancy density and interaction or physical contact between individuals facilitates the transmission and infestation of scabies mites. Therefore, the prevalence of high scabies is generally found in environments with occupant densities and high interpersonal contacts, such as prisons, orphanages, and Islamic boarding schools (Shelly \& Currie, 2007).

The results of a study conducted by Rohmawati (2010) found that $74.74 \%$ of respondents in Al-Muayyad Surakarta Islamic boarding school suffered from scabies due to their low knowledge of clean and healthy living behavior and they had twice the risk of scabies compared to respondents who had knowledge well. The same study was conducted by Hilma and Ghozali (2014), regarding the factors that influence the incidence of scabies in the Islamic boarding school in Yogyakarta. Based on the results of these studies, it was found that there was a relationship between the level of knowledge and the incidence of scabies. The results of these studies indicate that knowledge is very influential in the occurrence of diseases, especially infectious diseases such as scabies.

Various methods have been developed in the world of education in delivering messages aimed at increasing knowledge. The question and answer lecture method is a method that is quite effective as a message. This opinion is supported by the statement that the lecture method will be effective if coupled with question and answer, so that two-way communication 
and lecture will occur if there are teaching aids (WHO, 2003).

Delivery of messages through lectures needs to be assisted with modules, so participants can review the material discussed in the lecture (Utomo et al, 2014). Consideration of the use of modules because these media have advantages in terms of convenience to be stored and read repeatedly, involve many people, and make it easier for people to recall the contents of the message.

Based on this, the role of nurses is very much needed in improving one's personal skin hygiene through health education activities (counseling) and increasing knowledge about personal hygiene efforts through the application of the principles of clean and healthy life (Iqbal, 2005).

\section{METHODS}

\section{Study Design}

The study design was used preexperiment (one group pretest - posttest). The design of this study was not a comparison group (control), but the first observation (pretest) was carried out which allowed researchers to test changes that occurred after the experiment (Notoatmodjo, 2012).

\section{Setting}

This research was conducted in the Islamic boarding school Roudhotul Muta'alimin Muta'alimat, Jabon SubDistrict, Sidoarjo District, East Java Province, Indonesia.

\section{Research Subject}

The population in this study were all students who lived in the Islamic boarding school Roudhotul Muta'alimin Muta'alimat, Jabon Sub-District, Sidoarjo District, East Java Province, Indonesia in a total of 72 people. The size of the sample in this study was 60 people, determined by using probability sampling, with a simple random sampling technique.

\section{Instruments}

The independent variable in this study is the skin personal hygiene module, while the dependent variable is knowledge in prevention of scabies. The instrument used in this study is to use a tool in the form of modules and questionnaires.

\section{Data Analysis}

The analysis used was the Wilcoxon signed rank statistical test, with a significance level $\alpha<0.05$.

\section{Ethical Consideration}

This research has gone through an ethical test from the Nahdlatul Ulama University of Surabaya and obtained permission from National Unity and Politics of Sidoarjo Regency.

\section{RESULTS}

Characteristics of Respondents by Gender

Table 1. Distribution of Frequency of Respondents by Gender in the Islamic boarding school Roudhotul Muta'alimin Muta'alimat, Jabon Sub-District, Sidoarjo District, East Java Province, Indonesia ( $\mathrm{n}=$ 60).

\begin{tabular}{ccc}
\hline Gender & Frequency & Percentage (\%) \\
\hline Male & 40 & 66.7 \\
Female & 20 & 33.3 \\
\hline Total & 60 & 100.0 \\
\hline
\end{tabular}

Sources: Primary Data of Questionnaire, 2018

Based on table 1, it was found that the characteristics of respondents based on gender were mostly Male, as many as 40 respondents $(66.7 \%)$.

\section{Characteristics of Respondents by Age}

The results of study on table 2 found that the characteristics of respondents by age was 12-13 years, as many as 29 respondents $(48.3 \%)$. 
Table 2. Distribution of Frequency of Respondents by Age in the Islamic boarding school Roudhotul Muta'alimin Muta'alimat, Jabon Sub-District, Sidoarjo District, East Java Province, Indonesia $(\mathrm{n}=$ 60).

\begin{tabular}{ccc}
\hline Age (Years) & Frequency & Percentage (\%) \\
\hline $12-13$ & 29 & 48.3 \\
$14-15$ & 22 & 36.7 \\
$16-17$ & 4 & 6.7 \\
$18-19$ & 5 & 8.3 \\
\hline Total & 60 & 100.0 \\
\hline
\end{tabular}

Sources: Primary Data of Questionnaire, 2018

Characteristics of Respondents based on History of Skin Diseases

Table 3. Distribution of Frequency of Respondents based on History of Skin Diseases in the Islamic boarding school Roudhotul Muta'alimin Muta'alimat, Jabon Sub-District, Sidoarjo District, East Java Province, Indonesia $(n=60)$.

\begin{tabular}{ccc}
\hline $\begin{array}{c}\text { History of Skin } \\
\text { Diseases }\end{array}$ & Frequency & $\begin{array}{c}\text { Percentage } \\
(\boldsymbol{\%})\end{array}$ \\
\hline Never & 18 & 30 \\
Ever & 42 & 70 \\
\hline Total & 60 & 100 \\
\hline
\end{tabular}

Sources: Primary Data of Questionnaire, 2018

The results of study on table 3 found that mostly respondent had previously suffered from skin diseases, as many as 42 respondents $(70 \%)$.

Characteristic of Respondents by Knowledge Level

Table 4. Distribution of Frequency of Respondents by Knowledge Level in the Islamic boarding school Roudhotul Muta'alimin Muta'alimat, Jabon SubDistrict, Sidoarjo District, East Java Province, Indonesia $(n=60)$.

\begin{tabular}{ccccc}
\hline Knowledge Level & \multicolumn{2}{c}{ Pretest } & \multicolumn{2}{c}{ Posttest } \\
& $\mathrm{n}$ & $\%$ & $\mathrm{n}$ & $\%$ \\
\hline Good & 1 & 1,7 & 28 & 46,7 \\
Moderate & 26 & 43,3 & 32 & 53,3 \\
Low & 33 & 55,0 & 0 & 0 \\
\hline Total & 60 & 100 & 60 & 100 \\
\hline
\end{tabular}

Sources: Primary Data of Questionnaire, 2018
Based on the results of the study in table 4, it was found that the level of knowledge of respondents before being given treatment was a low level of knowledge about maintaining personal hygiene so as to avoid scabies by 33 respondents $(55.0 \%)$. After being given treatment, most of the respondents had moderate level of knowledge as much as 32 respondents $(53.3 \%)$.

Statistical Test Results to Determine the Effect of Providing Health Education by using Skin Personal Hygiene Modules on the Level of Knowledge in Preventing Scabies.

Table 5. The Results of Statistical Tests using the Wilcoxon Signed Ranks Test to Determine the Effect of Providing Health Education by using Skin Personal Hygiene Modules on The Level of Knowledge in Preventing the Occurrence of Scabies in the Islamic boarding school Roudhotul Muta'alimin Muta'alimat, Jabon SubDistrict, Sidoarjo District, East Java Province, Indonesia $(n=60)$.

\begin{tabular}{llccc}
\hline \multicolumn{2}{c}{ Variable } & $\mathbf{n}$ & $\mathbf{Z}$ & $\boldsymbol{p}$-value \\
\hline $\begin{array}{l}\text { Knowledge } \\
\text { level }\end{array}$ & $\begin{array}{l}\text { Pre test } \\
\text { Post test }\end{array}$ & 60 & $-7,496$ & 0,000 \\
Sources: Primary Data of Questionnaire, 2018 & \\
\hline
\end{tabular}

Based on the Wilcoxon Signed Ranks Test analysis showed a difference with a significant value $\mathrm{p}=0,000$ and significance level $\alpha<0.05$.

\section{DISCUSSION}

Based on the results of research conducted in the Islamic boarding school Roudlotul Muta'allimin-Muta'alimat, Jabon Sub-District, Sidoarjo District, East Java Province shows that almost half of the $48.3 \%$ are $12-13$ years old. The average age range of respondents in this study was 1219 years. Ages 13-20 are included in adolescence, adolescents of that age participate in health related to caring for themselves, therefore health education is 
very appropriate to do because at the age of adolescence they will try new roles including, starting to stabilize their identity, indigo and behavior obtained from the adult lifestyle included in it (Potter \& Perry, 2012). Based on the results of a study conducted by Rathore \& Saxena (2014) in a hospital with Tertiary Care, it was found that the incidence of scabies was most prevalent in respondents aged 11-20 years. While the results of a study conducted by Lassa et al. (2011) on epidemiology and the prevalence of scabies, it was found that scabies occurred mostly at the age of 10-19 years.

Based on the results of the study it was found that most of the respondents as many as 42 respondents (70\%) had suffered from skin diseases while living in the Islamic boarding school Roudlotul Muta'alliminMuta'alimat. It shows that most of the students have had experience in particular skin disease scabies. Experience is a source of knowledge and forming behavior (Walgito, 2010). Knowledge will be obtained by repeating the knowledge gained when solving problems encountered in the past.

Other respondents' characteristics related to their living environment were risk factors for transmission of scabies, where $100 \%$ of respondents in this study lived in the Islamic boarding schools. They say that they have a narrow room so they sleep together with friends/ relatives who suffer from scabies. This is in accordance with the research of Zeba et al (2014) which states that there is a relationship between occupant density and incidence of scabies. Baker et al. (2014) in his book say that direct contact, such as hugging and sharing a bed, can be a transmission medium for scabies mites. When students sleep coincides, there will be a possibility of direct contact from skin to skin which can be a medium for transmission of scabies mites.

Knowledge is an important thing that influences a person's behavior in maintaining their health from various diseases such as scabies. The knowledge of students about scabies based on the results of the study found an increase in the level of knowledge after being given health education using the module. Before being given an intervention, the results of the pretest were $1.7 \%$ of respondents with a good level of knowledge, $43.3 \%$ of respondents with moderate level of knowledge, and $55 \%$ of respondents with low level of knowledge. After being given an intervention in the form of health education there was an increase in the level of knowledge with posttest results $46.7 \%$ with a good level of knowledge, 53.3\% moderate level of knowledge and no respondents with low level of knowledge.

After receiving health education and being given a module on skin personal hygiene, respondents can easily receive information, because they can take the module home to read it again. So, when the post test was carried out, respondents were able to answer the questionnaire that had been distributed directly, and found an increase in the average score at the posttest compared to before being given health education about prevention of scabies.

Based on Wilxocon Rank Test, there is a significant difference in the increase of students' knowledge about prevention of scabies (significant value $\mathrm{p}=0,000$ and significance level $\alpha<0.05$ ). This is possible because of the variety of methods used in accordance with the characteristics of the respondents in the study, and the material related to scabies and prevention are packaged in the form of interesting pictures and writings in the form of modules, making them easier to understand and easily understood by respondents. In accordance with the opinion of Supratman (2003) that the purpose of health education is to change the understanding of individual groups and communities in the field of health in order to make health an independent value in achieving healthy 
living goals and to be able to use existing and appropriate health care facilities.

Dissemination of information on the use of other health education media, such as booklets, posters, leaflets in research and health education has been widely carried out and shows that there is an increase in knowledge. Research conducted by Setyowati (2005) in Jepara showed that after being given health education with leaflet media, the knowledge of the intervention group increased significantly compared to the control group. Research with module media also provided results of increased knowledge in the intervention group compared to the control group conducted by Arifah (2010).

According to Notoatmodjo (2012), knowledge is the result of human sensing or the result of knowing someone about objects through their senses. Health education as part of public health, functions as a medium or means to provide sociopsychological conditions in such a way that individuals or communities behave in accordance with the norms of healthy living, in other words health education aims to change the knowledge, attitudes and actions of individuals or communities so that in accordance with the norms of healthy living, education will affect health behavior, then health behavior will affect the increase in public health indicators (outcomes) in health education.

According to Aulia's (2014) study of the effect of health education on personal hygiene on knowledge and attitudes at SDN Rembes 1, it was found that the results of the t-test showed a $p$-value at $0.003(\alpha$ $<0.05)$, which means that there was an influence on health education on personal hygiene. knowledge of students at SDN Rembes 1.

\section{CONCLUSION}

The characteristics of the respondents in this study were mostly male, had suffered from skin diseases while living in the Islamic boarding schools, and almost half were 12-13 years old. The skin personal hygiene module as a health education media can increase knowledge in prevention of scabies. Based on the results of the study, it was found that there was the influence of the skin personal hygiene module as a media of health education on knowledge in the prevention of scabies.

\section{SUGGESTIONS}

To prevent scabies, health workers are expected to provide health education about the skin personal hygiene and make the PONKESTREN program more effective to participate in monitoring habits that can cause scabies in Islamic boarding schools.

\section{REFERENCES}

Arifah, S. (2010). Pengaruh Pendidikan Kesehatan dengan Modul dan Media Visual Terhadap Peningkatan Pengetahuan dan Sikap Wanita Dalam Menghadapi Menopause (Studi Eksperimen Pada Wanita Premenopause di Desa Sumber Mulyo). Publikasi Penelitian.

Azizah, N. N. (2013). Hubungan Antara Kebersihan Diri dan Lama Tinggal Dengan Kejadian Penyakit Skabies di Pon-Pes Al-Hamdulillah Rembang (Doctoral dissertation, Universitas Muhammadiyah Surakarta).

Baker F. (2014). Scabies management. Paediatric Child Health.

Baur, B., Sarkar, J., Manna, N., \& Bandyopadhyay, L. (2013). The pattern of dermatological disorders among patients attending the skin OPD of a tertiary care hospital in Kolkata, India. Journal of Dental and Medical Sciences, 3, 1-6.

Chosidow, O. (2006). Scabies. New England Journal of Medicine, 354(16), 1718-1727.

Departemen Kesehatan RI. 2007. Pedoman Penyelenggaraan dan Pembinaan Pos Kesehatan Pesantren. Retrieved from http://perpustakaan.depkes.go.id at 
January 25, 2018.

Golant, A. K., \& Levitt, J. O. (2012). Scabies: a review of diagnosis and management based on mite biology. Pediatrics in review, 33(1), e1-e12.

Harahap Marwali. (2008). Ilmu Penyakit Kulit. Jakarta: Hipokrates.

Hilma, U. D., \& Ghazali, L. (2014). FaktorFaktor Yang Mempengaruhi Kejadian Skabies Di Pondok Pesantren Mlangi Nogotirto Gamping Sleman Yogyakarta. JKKI: Jurnal Kedokteran dan Kesehatan Indonesia, 6(3), 148157.

Kuspriyanto. (2009). Pengaruh sanitasi dan higiene perorangan terhadap penyakit kulit. Surabaya: PPS Universitas Airlangga.

Lassa, S., Campbell, M. J., \& Bennett, C. E. (2011). Epidemiology of scabies prevalence in the UK from general practice records. British Journal of Dermatology, 164(6), 1329-1334.

Notoatmodjo, S. (2012). Promosi kesehatan dan perilaku kesehatan. Jakarta: Rineka Cipta.

Potter, P. A., \& Perry, A. G. (2012). Buku ajar fundamental keperawatan: konsep, proses, dan praktik. Jakarta: EGC.

Rathore p \& Sungkar S. (2014). Prevalence \& Risk Factors for Scabies among OPD Population of Tertiary Care Hospital Praveen Rathore Praveer Saxena Global Reseach Analysis, 2(11), 189-190.

Rahmawati, R. (2010). Hubungan Antara Faktor Pengetahuan Dan Perilaku Dengan Kejadian Skabies Di Pondok Pesantren Al-Muayyad Surakarta. (Skripsi). Fakultas Ilmu Kesehatan Masyarakat. Universitas Muhammadiyah Surakarta.

Shelley FW, Currie BJ. (2007). Problems in diagnosing scabies, a global disease in human and animal populations CMR.268-79.

Supratman. (2003). Dasar-Dasar
Kesehatan Masyarakat. Surakarta: Keperawatan Fakultas Ilmu KesehatanUMS.

Utomo, T., Wahyuni, D., \& Hariyadi, S. (2014). Pengaruh Model Pembelajaran Berbasis Masalah (Problem Based Learning) Terhadap Pemahaman Konsep dan Kemampuan Berpikir Kreatif Siswa (Siswa Kelas VIII Semester Gasal SMPN 1 Sumbermalang Kabupaten Situbondo Tahun Ajaran 2012/2013). Jurnal Edukasi, 1(1), 5-9.

Walgito, Bimo. (2010). Pengantar Psikologi Umum. Yogyakarta: Penerbit Andi.

Wijaya, Y. (2011). Faktor-Faktor yang Berhubungan dengan Kejadian

Skabies pada Santri di Pondok Pesantren Al-Makmur Tungkar Kabupaten 50 Kota Tahun 2011.

Zayyid, M. M., Saadah, R. S., Adil, A. R., Rohela, M., \& Jamaiah, I. (2010). Prevalence of scabies and head lice among children in a welfare home in Pulau Pinang, Malaysia. Tropical biomedicine, 27(3), 442-446.

Zeba, N., Shaikh, D. M., Memon, K. N., \& Khoharo, H. K. (2014). Scabies in relation to hygiene and other factors in patients visiting Liaquat University Hospital, Sindh, Pakistan. Age (years), 9, 10-19.

Cite This Article As: Wijayanti, L., Ainiyah, N. The Effect of the Skin Personal Hygiene Modules as Health Education Media Against Knowledge in Prevention of Skabies. Nurse and Health: Jurnal Keperawatan 2019; 8(1): $1-7$. 